\title{
PENYISIHAN KALIUM DARI LIMBAH CAIR PERSAWAHAN DENGAN METODE MULTI SOIL LAYERING (MSL)
}

\author{
Taufiq Ihsan, Shinta Indah dan Denny Helard \\ Laboratorium Air Jurusan Teknik Lingkungan Universitas Andalas \\ Email: taufiqihsan86@gmail.com
}

\begin{abstract}
ABSTRAK
Metode Multi Soil Layering (MSL) telah diujicobakan untuk menyisihkan kalium pada limbah cair persawahan. Lokasi pengambilan sampel berada di daerah Tunggang, Kelurahan Pasar Ambacang, Kecamatan Pauh, Kota Padang. Hasil analisis karakteristik limbah cair tersebut menunjukkan bahwa konsentrasi melebihi standar konsentrasi kalium pada air. Penelitian ini menggunakan 2 buah reaktor berbahan fiberglass, berbentuk trapesium untuk sisi tegaknya, dengan dimensi panjang dan lebar alas $37 \mathrm{~cm}$, panjang dan lebar sisi atas $44 \mathrm{~cm}$ dan tinggi $60 \mathrm{~cm}$, serta lapisan aerob berupa batuan kerikil berdiameter 3-5 mm. Kedua reaktor dibedakan atas material organik dalam campuran tanah pada lapisan anaerob, dimana reaktor 1 terdiri dari campuran tanah andisol dan arang, sedangkan reaktor 2 terdiri dari campuran tanah andisol dengan serbuk gergaji. Limbah cair ini dialirkan pada variasi konsentrasi antara 1,048 - 6,237 mg/l, serta pada Hydraulic Loading Rate (HLR) dengan variasi 1.000, 2.000, dan $4.000 \mathrm{l} / \mathrm{m}^{2}$ hari. Hasil penelitian menunjukkan bahwa kedua reaktor mampu menyisihkan kalium mencapai $100 \%$ baik pada reaktor 1, maupun pada reaktor 2. Variasi material organik dalam campuran tanah pada lapisan anaerob, variasi konsentrasi influen, dan variasi HLR berpengaruh pada penyisihan kalium. Efisiensi penyisihan kalium didapatkan lebih tinggi pada reaktor 2 pada variasi konsentrasi influen terkecil, dengan pengaliran limbah cair pada HLR $1000 \mathrm{l} / \mathrm{m}^{2}$ hari. Secara umum MSL dapat diaplikasikan pada pengolahan limbah cair persawahan.
\end{abstract}

Kata Kunci : Limbah cair persawahan, MSL, kalium

\begin{abstract}
Multi Soil Layering (MSL) Methods has been tested to eliminate potassium in wastewater of rice fields. Sampling sites were in Tunggang, Pasar Ambacang, District Pauh, Padang. The results of the analysis of the characteristics of the wastewater showed that the concentration exceeds the standard concentration of potassium in water. This study uses 2 reactor made of fiberglass, trapezoid shape, with dimensions of length and base width $37 \mathrm{~cm}$, length and width of the upper $44 \mathrm{~cm}$ and high $60 \mathrm{~cm}$. The aerobic layers of gravel in the diameter of 3-5 mm. Both reactors are distinguished on the organic material in the soil mix in the anaerobic layer, wherein the reactor 1 consists of a mixture of soil and charcoal Andisol, while the second reactor consists of a mixture of soil Andisol with sawdust. Wastewater is discharged at various concentration between 1.048 to 6.237 $m g / l$, as well as on Hydraulic Loading Rate (HLR) with variation of 1,000; 2,000; and 4,000 l/m2.day. The results showed that both reactors are capable of removing potassium reaches $100 \%$ better at reactor 1 , and at reactor 2. Variations of organic material in the soil mixture in anaerobic layers, variations in influent concentration, and variations HLR effect on the allowance of potassium. Potassium removal efficiency obtained was higher in reactor 2 at the smallest variation of the influent concentration, the liquid waste stream in HLR $1000 \mathrm{l} / \mathrm{m} 2$. day. In general, MSL can be applied to the treatment of wastewater rice fields.
\end{abstract}

Keywords : Wastewater of rice fields, MSL, potassium 


\section{PENDAHULUAN}

Melihat pertambahan jumlah penduduk dan pentingnya sektor pertanian dalam kegiatan masyarakat Indonesia, diperlukan usaha untuk menghindari terjadinya gangguan terhadap kesehatan manusia dan lingkungan, sebaiknya sebelum limbah cair dibuang ke badan air, perlu dilakukan suatu pengolahan yang bertujuan untuk mengurangi konsentrasi senyawa-senyawa organik yang terkandung di dalamnya.

Kalium adalah salah satu unsur hara yang diperlukan untuk kesuburan tanaman, selain unsur natrium dan pospat (Richards, 1997). Hal ini mengakibatkan kalium menjadi salah satu unsur yang terkandung dalam pupuk. Kalium berperan sebagai pengatur proses fisiologi tanaman seperti fotosintetis, akumulasi, translokasi, transportasi karbohidrat, membuka menutupnya stomata, atau mengatur distribusi air dalam jaringan dan sel. Kekurangan unsur ini menyebabkan daun seperti terbakar dan akhirnya gugur. Jika unsur kalium berlebih, gejalanya mirip tanaman kekurangan kalsium (Novizan, 2006). Pada perairan, seperti unsur nitrogen dan pospat, kelebihan kalium juga dapat menimbulkan terjadinya eutrofikasi pada badan air seperti sungai, sehingga menyebabkan pertumbuhan tanaman air yang di luar kendali. Oksigen yang seharusnya digunakan bersama oleh seluruh hewan/tumbuhan air, menjadi berkurang akibat ledakan pertumbuhan tersebut (Rauf, 2000)

Banyak metode yang diterapkan untuk mengolah limbah cair agar tidak mencemari lingkungan sekitar dan ekosistem perairan. Salah satunya yaitu metode Multi Soil Layering (MSL). Menurut Masunaga (2007) metode MSL adalah metode pengolahan yang memanfaatkan kemampuan tanah dalam mengolah limbah cair, dimana tanah disusun dalam pola batu bata. Metode ini dikenal murah dari segi biaya, tetapi membutuhkan lahan yang luas jika dibandingkan dengan sistem pengolahan mekanis atau teknis. MSL juga dikenal sederhana, mudah dari segi pengoperasian dan pengontrolan, serta bersifat ramah lingkungan (Salmariza dkk, 2001-2003).

Penelitian ini mempelajari kinerja MSL dalam menyisihkan kalium dari limbah cair pertanian yang berasal dari persawahan. Penelitian dilakukan pada variasi konsentrasi dan variasi HLR (Hydraulic Loading Rate), dengan menggunakan 2 reaktor yang dibedakan lapisan anaerobnya, yakni campuran tanah dan arang pada reaktor 1 serta campuran tanah dan serbuk gergaji pada reaktor 2 . Selain variasi material organik, juga variasi konsetrasi, dan variasi HLR. Dengan mempertimbangkan variasi tersebut, maka diperoleh desain MSL yang lebih baik.

\section{METODOLOGI PENELITIAN}

\section{Sampel Limbah Persawahan}

Sampel yang digunakan merupakan sampel asli persawahan yang diambil dari sawah daerah Tunggang, Kelurahan Pasar Ambacang, Kecamatan Kuranji, Padang. Air limbah persawahan yang dijadikan sampel ini berasal dari 5 petak sawah yang dialiri secara bertingkat. Pengambilan sampel dilakukan pada saluran pembuangan terakhir yang menuju badan air.

\section{Persiapan Reaktor}

Persiapan reaktor ini bertujuan untuk mengetahui spesifikasi reaktor MSL yang digunakan, seperti bahan dan dimensi, komposisi lapisan material penyusun, dan berat material dalam lapisan anaerob. 


\section{Komposisi lapisan material penyusun reaktor}

a. Lapisan Aerob

Lapisan batuan yang digunakan untuk kedua reaktor MSL ini adalah kerikil. Kerikil yang digunakan merupakan hasil saringan yang berukuran 3-5 mm. Penggunaan kerikil dengan ukuran yang sama bertujuan untuk menghindari terjadinya clogging. Pemilihan batu jenis kerikil dilakukan karena mudah didapat dan murah.

b. Lapisan Anaerob

Reaktor yang digunakan dalam penelitian ini terdiri dari 2 buah reaktor dengan komposisi lapisan material penyusun berbeda pada masing-masing reaktor. Perbedaan tersebut terdapat pada penggunaan lapisan campuran tanah sebagai lapisan anaerob, dimana pada reaktor 1 ini digunakan campuran tanah dengan arang sedangkan pada reaktor 2 digunakan campuran tanah dengan serbuk gergaji.

Tanah yang digunakan adalah tanah andisol yang merupakan tanah humus yang diambil dari Gunung Merapi, Kota Padang Panjang. Tanah andisol ini dipilih karena kaya akan humus dan mempunyai permukaan bidang adsorpsi lebih luas, berbutir halus sehingga dapat mencegah penyumbatan (clogging), dan belum terkontaminasi oleh pencemar sehingga kondisinya masih murni. Tanah andisol ini kemudian dicampur dengan arang dan serbuk gergaji. Selain untuk membantu proses adsorpsi bahan organik, arang juga berperan cukup penting dalam proses adsorpsi warna. Arang yang digunakan adalah arang halus dari hasil pembakaran batok kelapa karena lebih baik dalam menjernihkan air dan lebih tahan lama dibandingkan dengan arang kayu.

Serbuk gergaji yang digunakan adalah hasil pekerjaan konstruksi kayu. Serbuk gergaji dapat memperkaya sumber karbon untuk kelangsungan hidup mikroorganisme.

c. Pengukuran/Analisis Kadar Air Dari pengukuran kadar air dan bulk density, maka dapat ditentukan jumlah total material lapisan anaerob (campuran tanah dan arang serta campuran tanah dengan serbuk gergaji) yang diperlukan untuk menyusun kedua reaktor. Diperkirakan rasio berat komposisi lapisan anaerob yang digunakan adalah:

tanah : arang $\quad=2: 1$

tanah : serbuk gergaji $=2: 1$

Pemasangan dan Penyusunan Lapisan Aerob dan Lapisan Anaerob Campuran tanah dengan arang atau serbuk gergaji dibentuk menjadi bentuk batu bata, dengan dimensi panjang 10 $\mathrm{cm}$, lebar $38 \mathrm{~cm}$ (berbeda tiap lapisan) dan tinggi $5 \mathrm{~cm}$. Jarak antar batu bata 3 $\mathrm{cm}$ dan jarak antara lapisan pertama dengan lapisan kedua $5 \mathrm{~cm}$. Di antara susunan batu bata tersebut diisi dengan kerikil dan sebagai pembatas digunakan kayu reng dengan panjang $10 \mathrm{~cm}$, lebar $38 \mathrm{~cm}$ dan tinggi $5 \mathrm{~cm}$.

\section{Penyusunan Reaktor}

Reaktor yang digunakan terdiri dari 2 unit, berbentuk trapesium, dengan dimensi luas alas $37 \times 37 \mathrm{~cm}$, luas sisi atas $44 \mathrm{x} 44 \mathrm{~cm}$ dan tinggi $60 \mathrm{~cm}$, dilengkapi dengan pipa inlet $1 / 2$ inch (di permukaan lapisan batuan paling atas 
atau penutup), dan pipa outlet $1 / 2$ inch (di bagian bawah reaktor). Reaktor MSL juga dilengkapi bak influen yang berfungsi sebagai bak penampung limbah untuk mengalirkan ke dalam reaktor MSL yang diletakkan di atas tatakan yang outletnya berada lebih tinggi dari reaktor, sehingga outlet tangki tersebut lebih mudah mengalirkan limbah ke inlet reaktor dengan menggunakan selang, serta bak efluen yang digunakan untuk menampung limbah cair keluaran dari reaktor. Di dalam reaktor 1 ditumpuk lapisan campuran tanah dengan arang dan kerikil. Sedangkan pada reaktor 2 ditumpuk lapisan tanah dengan serbuk gergaji dan kerikil.

Peralatan pendukung MSL terdiri dari :

a. Holding tank, yang berguna untuk menampung air limbah yang akan diuji sebelum dialirkan ke dalam MSL.

b. Pipa Inlet, yang berfungsi mengalirkan limbah ke dalam reaktor MSL.

c. Pipa Outlet, yang berfungsi untuk mengalirkan air yang telah melewati reaktor MSL.

d. Tangki Efluen, yang berfungsi untuk menampug hasil olahan limbah cair oleh MSL.

Adapun sketsa reaktor MSL dapat dilihat pada Gambar 1 dan pada Gambar 2 dapat dilihat sketsa perletakan peralatan MSL

\section{Percobaan Pendahuluan}

Dalam penentuan waktu detensi, percobaan dilakukan dengan menggunakan air bersih dan menggunakan limbah cair yang diencerkan atau konsentrasinya lebih rendah dengan HLR tertentu yang telah direncanakan untuk pengolahan.

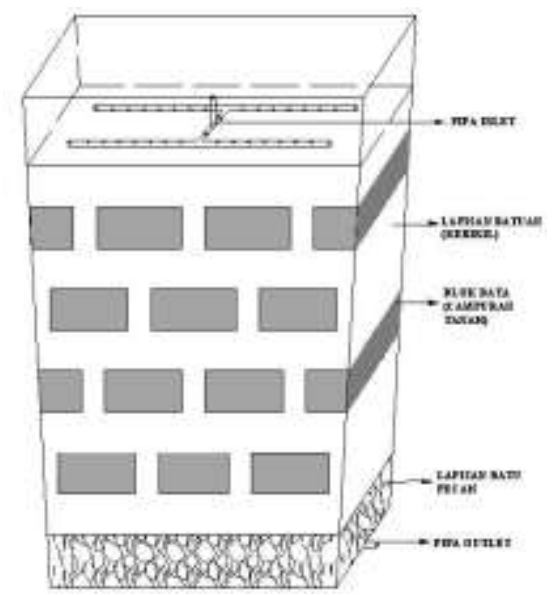

Gambar 1. Sketsa Konstruksi Reaktor MSL

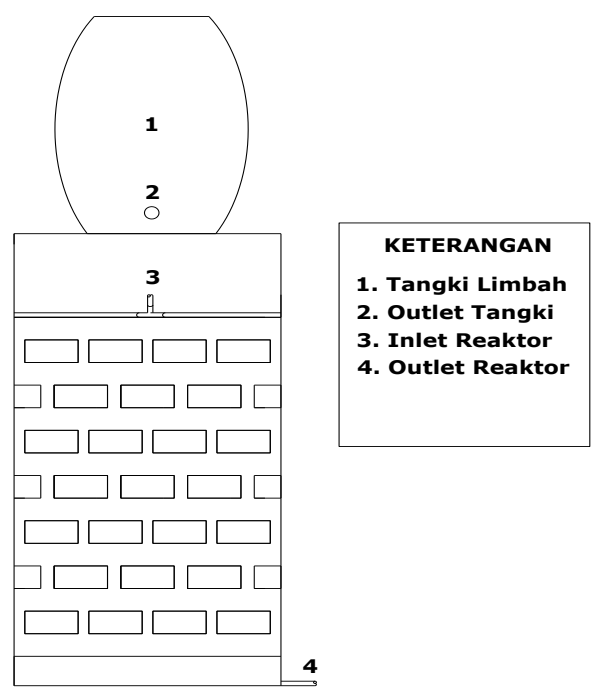

Gambar 2. Sketsa Perletakan Peralatan MSL

Penentuan waktu detensi pada penelitian ini dibagi atas 5 tahap percobaan, yakni:

1. Pengaliran air bersih dengan HLR 1.000, 2.000 dan $4.0001 / \mathrm{m}^{2}$ hari pada reaktor 1 sebanyak 15 kali percobaan (5 kali percobaan per masing-masing HLR);

2. Pengaliran air bersih dengan HLR 1.000, 2.000 dan $4.000 \mathrm{l} / \mathrm{m}^{2}$ hari pada reaktor 2 sebanyak 15 kali percobaan (5 kali percobaan per masing-masing HLR);

3. Pengaliran limbah cair dengan HLR $1.000 \mathrm{l} / \mathrm{m}^{2}$ hari pada kedua reaktor sampai kondisi tunak; 
4. Pengaliran limbah cair dengan HLR $2.0001 / \mathrm{m}^{2}$ hari pada kedua reaktor sampai kondisi tunak;

5. Pengaliran limbah cair dengan HLR $4.0001 / \mathrm{m}^{2}$ hari pada kedua reaktor sampai kondisi tunak.

Dalam proses pengujian pendahuluan, parameter yang dianalisis adalah kondisi efluen outlet kedua reaktor secara fisik dan kimia. Analisis kondisi fisik terdiri dari warna dan bau, sedangkan analisis kondisi kimia terdiri dari konsentrasi COD per 15 menit pengambilan sampel efluen reaktor.

\section{Percobaan Utama}

Percobaan utama dalam penelitian ini bertujuan untuk melihat kinerja reaktor MSL dengan variasi:

- Material organik pada lapisan anaerob dalam reaktor dimana menggunakan campuran tanah dengan arang untuk reaktor 1 dan campuran tanah dengan serbuk gergaji untuk reaktor 2 .

- Variasi Konsentrasi Influen

- Variasi HLR

\section{Analisis Laboratorium}

Analisis laboratorium yang dilakukan merupakan analisis data hasil pengolahan sampel limbah cair persawahan terhadap penyisihan kalium. Metode analisis kalium yang digunakan adalah AAS (Atomic Absorption Spektrofotometri). Data yang telah diolah kemudian dianalisis dan dibandingkan dengan konsentrasi limbah cair sebelum dan setelah masuk reaktor.

\section{HASIL DAN PEMBAHASAN}

\section{Analisis Karakteristik Limbah Cair Persawahan}

Pengambilan sampel dilakukan pada saluran sebelum limbah sampai ke badan air penerima. Sampel yang diambil yaitu pada hari pertama pengaliran, hari ketiga dan hari kelima, karena pemilihan waktu tersebut dianggap telah mewakili. Karakteristik limbah cair persawahan yang digunakan sebagai sampel, dapat dilihat pada Tabel 1 berikut.

Tabel 1. Karakteristik Limbah Cair Persawahan di Daerah Tunggang

\begin{tabular}{|c|c|c|c|c|}
\hline \multirow[b]{2}{*}{ Parameter } & \multirow[b]{2}{*}{ Satuan } & \multicolumn{3}{|c|}{$\begin{array}{c}\text { Sampel Limbah Cair } \\
\text { Pertanian }\end{array}$} \\
\hline & & $\begin{array}{c}\text { Sampel } \\
1 \\
(29 \\
\text { April } \\
2009)\end{array}$ & $\begin{array}{c}\text { Sampel } \\
2 \\
(1 \mathrm{Mei} \\
2009)\end{array}$ & $\begin{array}{c}\text { Sampel } \\
3 \\
(3 \text { Mei } \\
\text { 2009) }\end{array}$ \\
\hline COD & $\mathrm{mg} / \mathrm{l}$ & 48,546 & 51,463 & 2,451 \\
\hline $\begin{array}{l}\text { Senyawa } \\
\text { Fosfor: } \\
\text { - Total } \\
\text { Fosfat }\end{array}$ & $\mathrm{mg} / \mathrm{l}$ & 0,701 & 1,747 & 5,166 \\
\hline - Ortofosfat & $\mathrm{mg} / \mathrm{l}$ & 0,188 & 0,328 & 1,534 \\
\hline $\begin{array}{l}\text { - Total } \\
\text { Fosfor }\end{array}$ & $\mathrm{mg} / \mathrm{l}$ & 0,889 & 2,704 & 6,699 \\
\hline $\begin{array}{l}\text { Senyawa } \\
\text { Nitrogen } \\
\text { - Total } \\
\text { Nitrogen }\end{array}$ & $\mathrm{mg} / \mathrm{l}$ & 1,494 & 0,671 & 5,293 \\
\hline $\begin{array}{l}\text { - Total } \\
\text { Kjedalh } \\
\text { Nitrogen }\end{array}$ & $\mathrm{mg} / \mathrm{l}$ & 0,032 & 0,016 & 0,065 \\
\hline $\begin{array}{l}\text { - Nitrogen } \\
\quad \text { Anorganik } \\
\end{array}$ & $\mathrm{mg} / \mathrm{l}$ & 1,462 & 0,655 & 5,228 \\
\hline Kalium & $\mathrm{mg} / \mathrm{l}$ & 6,237 & 3,025 & 2,118 \\
\hline
\end{tabular}

\section{Penentuan Debit Pengolahan Limbah} Cair

Pengaliran limbah cair dilakukan pada HLR 1000, 2000 dan $4000 \mathrm{l} / \mathrm{m}^{2}$ hari. HLR merupakan besarnya laju pembebanan hidrolis limbah cair terhadap suatu bidang permukaan dalam satuan waktu tertentu. Untuk dapat menentukan HLR suatu aliran, maka perlu diketahui debit alirannya. Berikut hubungan HLR dengan debit secara matematis dapat dilihat pada persamaan 4.1.

$\mathrm{Q}_{\mathrm{HLR}}=\mathrm{HLR} \times$ luas bidang permukaan..

Dari persamaan 4.1, didapatkan debit yang dibutuhkan untuk HLR $1000 \quad 1 / \mathrm{m}^{2}$ hari adalah 134,44 ml/menit, untuk 2000 $1 / \mathrm{m}^{2}$ hari adalah $268,89 \mathrm{ml} / \mathrm{menit}$, dan 
untuk HLR $40001 / \mathrm{m}^{2}$ hari adalah 537,78 $\mathrm{ml} / \mathrm{menit}$.

\section{Percobaan Pendahuluan}

Penentuan Waktu Detensi (Detention Time, td)

Waktu detensi dihitung dalam 4 tahap percobaan meliputi pengaliran air kran dan limbah cair. Waktu detensi rata-rata reaktor 1 untuk HLR 1.000, 2.000 dan $4.000 \mathrm{l} / \mathrm{m}^{2}$.hari adalah $16,4,8$ menit, sedangkan pada reaktor 2 HLR 1.000, 2.000 dan $4.0001 / \mathrm{m}^{2}$.hari adalah 10,6 , 3menit.

\section{Pengamatan Kondisi Fisik dan Kimia Efluen Reaktor}

Untuk dapat memastikan reaktor dalam keadaan tunak, maka perlu diamati kondisi fisik dan kimia efluen limbah yang keluar dari outlet reaktor. Pengamatan kondisi fisik berhubungan dengan warna serta bau efluen, sedangkan secara kimia, reaktor dikatakan tunak jika memiliki nilai COD pada efluen yang relatif seragam. Limbah cair dialirkan dengan HLR $1000 \mathrm{l} / \mathrm{m}^{2}$ hari. Pengamatan dilakukan pada efluen sampel yang diambil setiap 15 menit selama 90 menit (satu setengah jam).

Hasil pengamatan kondisi fisik efluen yang dihasilkan kedua reaktor cenderung bening dan hampir tidak berwarna. Bau efluen pada reaktor tidak ada, sementara pada reaktor 2 berbau serbuk gergaji. Pengamatan kondisi COD menunjukkan konsentrasi COD efluen reaktor 1 dan 2 stabil pada 15 menit ke 4 pengaliran efluen. Ini dapat dilihat pada Gambar 3.

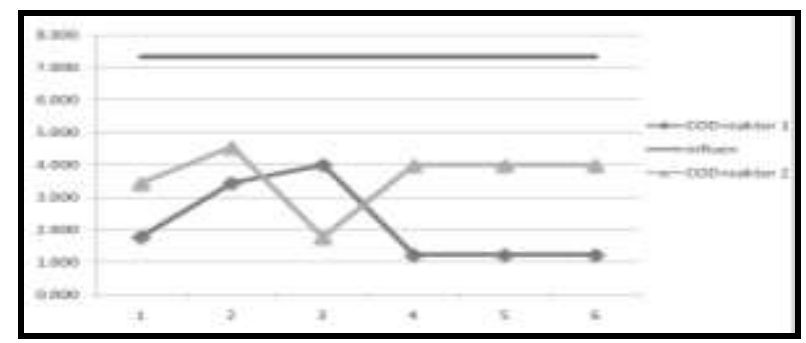

Gambar 3. Konsentrasi COD Efluen per 15 menit

\section{Percobaan Utama}

\section{Penurunan Konsentrasi Kalium}

Tabel 2. Rekapitulasi Penurunan Konsentrasi Kalium Limbah Cair Persawahan Kota Padang menggunakan Reaktor MSL

\begin{tabular}{|c|c|c|c|c|}
\hline \multirow{3}{*}{ Variasi } & \multicolumn{2}{|c|}{ Reaktor I } & \multicolumn{2}{|c|}{ Reaktor 2} \\
\hline & \multicolumn{2}{|c|}{ Konsentrasi (mg/l) } & \multicolumn{2}{|c|}{$\begin{array}{c}\text { Konsentrasi } \\
(\mathrm{mg} / \mathrm{l})\end{array}$} \\
\hline & Influen & Efluen & Influen & Efluen \\
\hline \multicolumn{5}{|c|}{ Pengaliran dengan HLR 1000 l/m² hari } \\
\hline Sampel 1 & 6,237 & 1,789 & 1,459 & 0 \\
\hline Sampel 2 & 3,025 & 1,624 & 1,624 & 0 \\
\hline Sampel 3 & 2,118 & 0,718 & 1,212 & 0 \\
\hline \multicolumn{5}{|c|}{ Pengaliran dengan HLR 2000 l/m² hari } \\
\hline Sampel 1 & 2,860 & 1,459 & 3,766 & 1,624 \\
\hline Sampel 2 & 1,542 & 1,048 & 3,272 & 0 \\
\hline Sampel 3 & 1,212 & 0 & 1,048 & 0 \\
\hline \multicolumn{5}{|c|}{ Pengaliran dengan HLR $4000 \mathrm{l} / \mathrm{m}^{2} \mathrm{hari}$} \\
\hline Sampel 1 & 3,272 & 2,942 & 2,118 & 1,707 \\
\hline Sampel 2 & 2,695 & 2,613 & 1,624 & 0 \\
\hline Sampel 3 & 1,707 & 0,800 & 1,954 & 0 \\
\hline
\end{tabular}

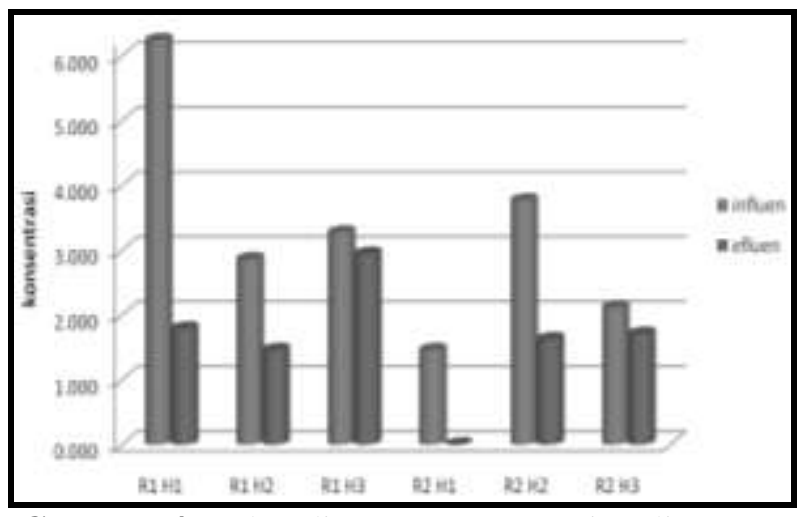

Gambar 4.Perbandingan Konsentrasi Kalium Influen-Efluen Sampel 1

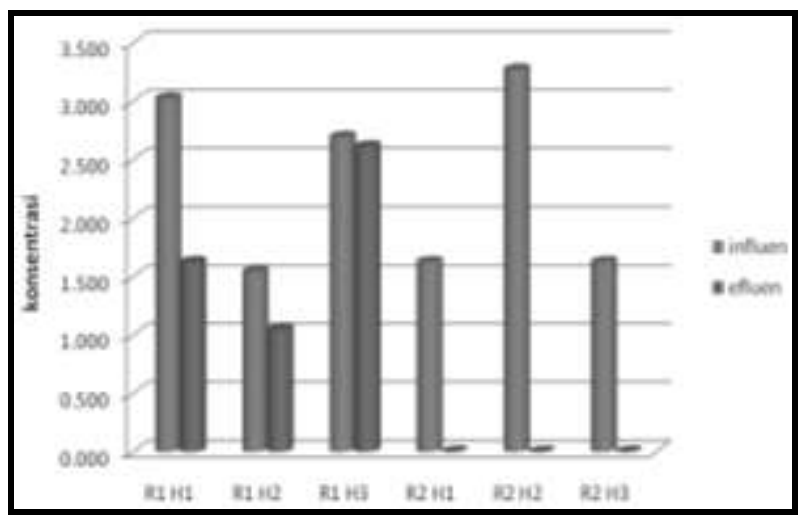

Gambar 5 Perbandingan Konsentrasi Kalium Influen-Efluen Sampel 2 


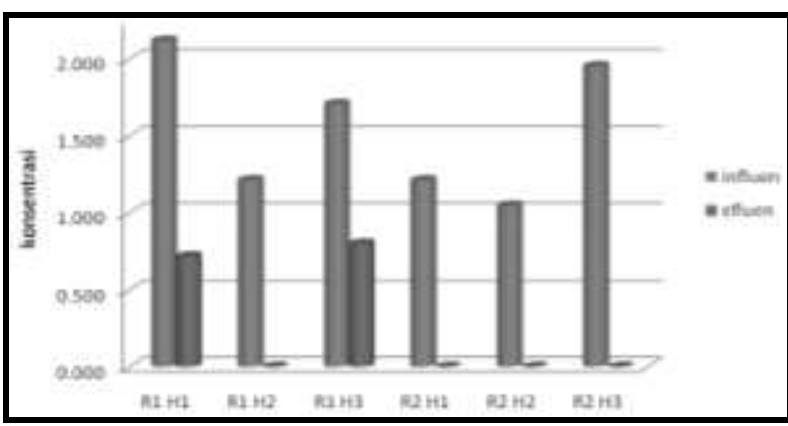

Gambar 6. Perbandingan Konsentrasi Kalium Influen-Efluen Sampel 3

Dapat disimpulkan berdasarkan Tabel 2 dan Gambar 4 sampai dengan Gambar 6, bahwa pada umumnya kalium tersisihkan dengan baik, bahkan hingga menjadi 0 $\mathrm{mg} / \mathrm{l}$. Ini membuktikan, MSL mampu menyisihkan konsentrasi kalium pada limbah cair pertanian dengan baik

Pengaruh Faktor Variasi Material Organik dengan Campuran Tanah pada Lapisan Anaerob terhadap Efisiensi Penyisihan Konsentrasi Kalium pada Variasi HLR (Hydraulic Loading Rate)

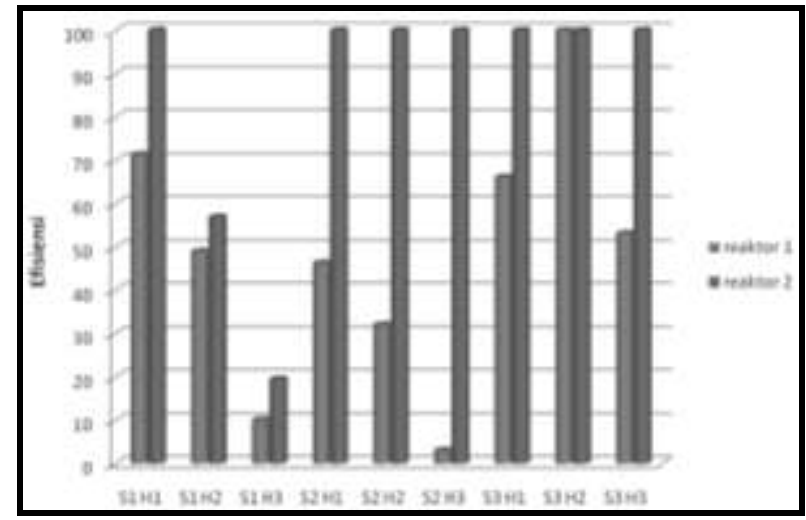

Gambar 7. Efisiensi Penyisihan Konsentrasi Kalium Limbah Cair Persawahan pengaruh HLR

Pada Tabel 3 dan Gambar 7, dapat dilihat bahwa reaktor 2 selalu lebih baik dalam menyisihkan kalium berdasarkan HLR. Hal ini dapat dilihat berdasarkan besarnya efisiensi penyisihan reaktor 2 pada masingmasing konsentrasi untuk peruntukan tiap HLR

\section{Efisiensi Penyisihan Konsentrasi Kalium Limbah Cair}

Tabel. 3 Efisiensi Penyisihan Konsentrasi Kalium Limbah Cair Persawahan oleh Reaktor MSL

\begin{tabular}{|c|c|c|c|}
\hline Reaktor & Sampel & $\begin{array}{c}\text { HLR }\left(\mathrm{l} / \mathrm{m}^{2}\right. \\
\text { hari) }\end{array}$ & $\begin{array}{l}\text { Efisiensi Penyisihan } \\
\text { Efluen }\end{array}$ \\
\hline \multirow{9}{*}{1} & 1 & \multirow{3}{*}{1000} & 71,319 \\
\hline & 2 & & 46,302 \\
\hline & 3 & & 66,107 \\
\hline & 1 & \multirow{3}{*}{2000} & 48,969 \\
\hline & 2 & & 32,058 \\
\hline & 3 & & 100 \\
\hline & 1 & \multirow{3}{*}{4000} & 10,072 \\
\hline & 2 & & 3,507 \\
\hline & 3 & & 53,100 \\
\hline \multirow{9}{*}{2} & 1 & \multirow{3}{*}{1000} & 100 \\
\hline & 2 & & 100 \\
\hline & 3 & & 100 \\
\hline & 1 & \multirow{3}{*}{2000} & 56,873 \\
\hline & 2 & & 100 \\
\hline & 3 & & 100 \\
\hline & 1 & \multirow{3}{*}{4000} & 19,443 \\
\hline & 2 & & 100 \\
\hline & 3 & & 100 \\
\hline
\end{tabular}

Pengaruh Faktor Variasi Konsentrasi Influen terhadap Efisiensi Penyisihan Konsentrasi Kalium

Berdasarkan Gambar 8 dan 9, dapat disimpulkan, semakin kecil konsentrasi unsur kalium pada influen yang digunakan dalam penyisihan dengan metode MSL, maka semakin baik dalam efisiensi penyisihan.

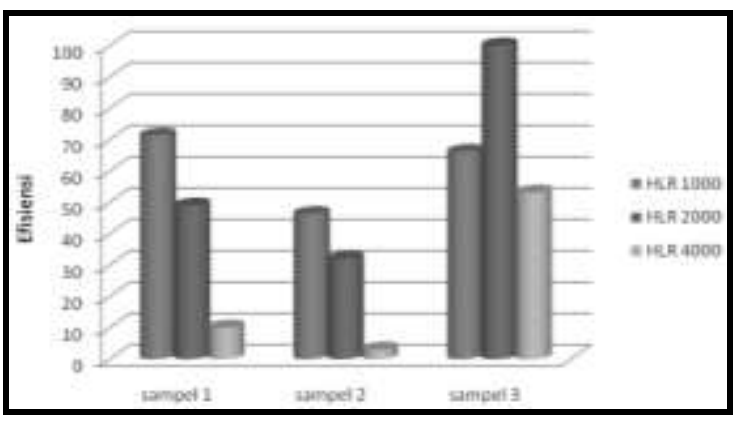

Gambar 8. Efisiensi Penyisihan Konsentrasi Kalium pada Reaktor 1 Pengaruh Variasi Konsentrasi 


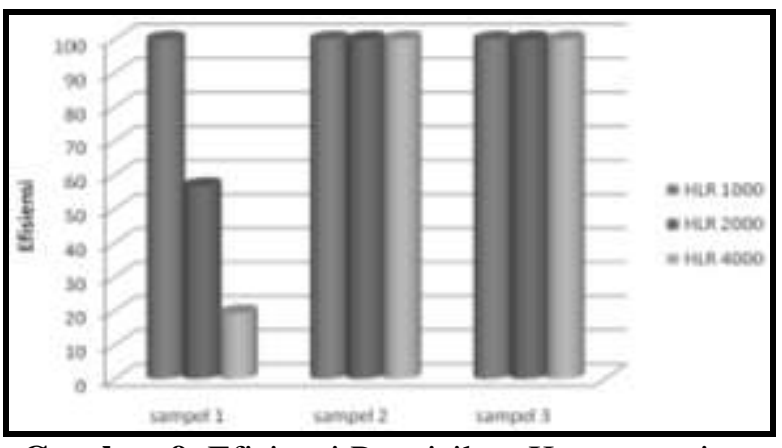

Gambar 9. Efisiensi Penyisihan Konsentrasi Kalium pada Reaktor 2 Pengaruh Variasi Konsentrasi

\section{Pengaruh Faktor Variasi HLR terhadap Efisiensi Penyisihan Konsentrasi Kalium}

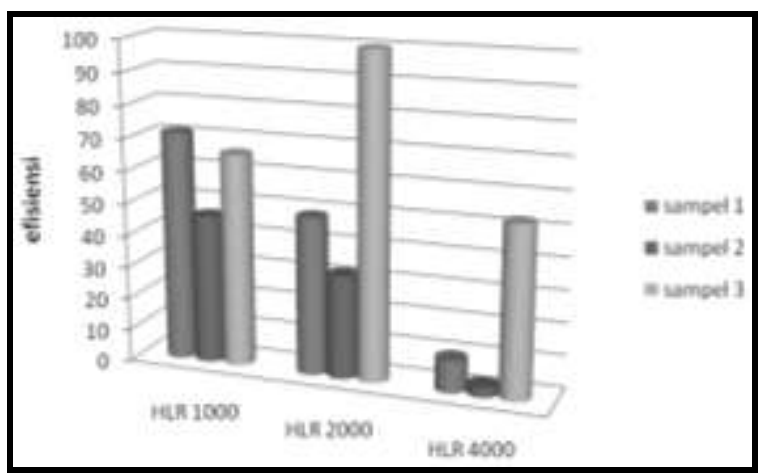

Gambar 10 Efisiensi Penyisihan Konsentrasi Kalium Reaktor 1 pengaruh variasi HLR

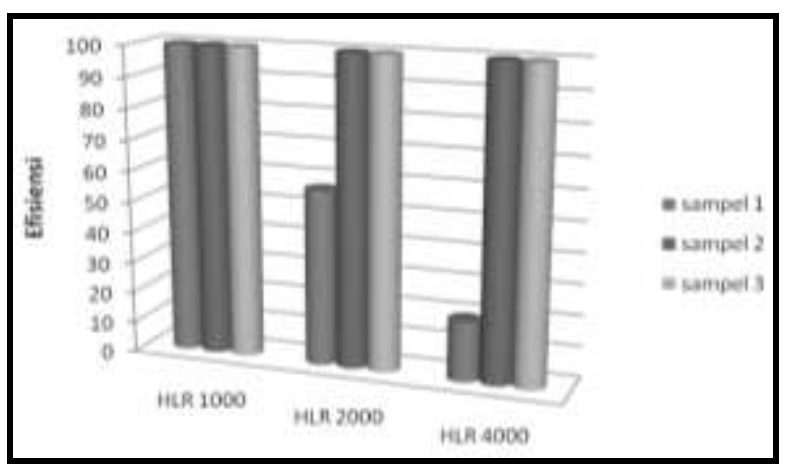

Gambar 11 Efisiensi Penyisihan Konsentrasi Kalium Reaktor 2 pengaruh variasi HLR Pada Gambar 10 dan 11, terlihat kalau efisiensi penyisihan sangat bagus pada HLR 1000 1/m $\mathrm{m}^{2}$.hari (mencapai 100\% untuk ketiga sampel pada reaktor 2), disusul berturut-turut $2000 \mathrm{l} / \mathrm{m}^{2}$.hari dan $4000 \mathrm{l} / \mathrm{m}^{2}$.hari. Dapat disimpulkan bahwa, penggunaan HLR $1000 \quad 1 / \mathrm{m}^{2}$.hari mempunyai efisiensi yang lebih tinggi dalam menyisihkan konsentrasi kalium dibandingkan dengan HLR $20001 / \mathrm{m}^{2}$.hari dan $4000 \mathrm{l} / \mathrm{m}^{2}$.hari.

\section{IMPULAN}

Berdasarkan hasil penelitian pengolahan limbah cair persawahan dengan lokasi sampel daerah Tunggang, Kelurahan Pasar Ambacang, Kecamatan Kuranji, Padang, dengan metode Multi Soil Layering (MSL) yang telah dilakukan, dapat disimpulkan beberapa hal, antara lain:

Limbah cair persawahan yang digunakan, dengan konsentrasi 1,212 - 6,237 mg/l, tergolong tinggi jika dibandingkan dengan kandungan konsentrasi kalium yang diperbolehkan pad air laut yang menampung limbah cair industri dan limbah cair pertanian $(0,38 \mathrm{mg} / \mathrm{l})$.

Efisiensi penyisihan kalium pada reaktor 1 (lapisan anaerob campuran tanah andisol dan arang) berkisar antara 3,057 - 100\%, dan pada reaktor 2 (lapisan anaerob campuran tanah andisol dengan serbuk gergaji) berkisar antara 19,443 - 100\%.

Variasi lapisan anaerob sangat berpengaruh dalam penyisihan kalium pada limbah cair persawahan. Dimana reaktor 2 dengan lapisan anaerob berupa campuran serbuk gergaji dan tanah, lebih baik daripada reaktor 1 dengan campuran tanah dan arang sebagai lapisan anaerobnya.

Variasi konsentrasi berpengaruh terhadap penyisihan kalium, dimana didapatkan efisiensi tertinggi pada konsentrasi kalium yang paling rendah.

Variasi HLR yang digunakan berpengaruh terhadap penyisihan kalium pada limbah cair persawahan, dimana semakin HLR, maka semakin tinggi efisiensi penyisihan.

Pengolahan dengan metode MSL terbukti mampu menurunkan konsentrasi unsur kalium pada limbah cair persawahan.

\section{DAFTAR PUSTAKA}

Masunaga, T. 2007. Characteristic of Waswater Treatment Using A Multi-soil-Layering System In Relation To Waswater Contaminan Levels and Hydraulic Loading Rate. Soil Science and Plat Nutrition. 
Nassar, Ateef dan Reham El-Korashey. 2003. Sustainable Development Reuse and Wastewater Seventh International Water Technology Conference Egypt 1-3 April 2003. Egypt

Novizan. 2006. Petunjuk Pemupukan yang Efektif. Agromedia: Jakarta.

Rauf, A.W, dkk. 2000. Peranan Pupuk NPK pada Tanaman Padi. Badan Penelitian dan Pengembangan Pertanian. Irian Jaya

Richards, J.H., D.J.,Cram, G.S., Hammond. 1997. Elements of Organic Chemistry. McGraw-Hill Book, Company. New York
Salmariza. 2001. Minimalisasi Pencemaran Industri Sawit dengan Metode MSL. Laporan Penelitian. Baristand Indag:Padang.

Salmariza. 2002. Minimalisasi Pencemaran Industri Crumb Rubber dengan Metode MSL. Laporan Penelitian. Baristand Indag: Padang.

Salmariza. 2003. Penelitian Efisiensi Kinerja Sistem MSL untuk Pengolahan Limbah Cair Industri Crumb Rubber. Laporan Penelitian. Baristand Indag: Padang.

Salmariza. 2003. Minimalisasi Pencemaran Industri Tahu dengan Metode MSL. Laporan Penelitian. Baristand Indag: Padang. 